\title{
Variation and Change in Ancient Greek Tense, Aspect and Modality
}

\author{
Edited by
}

Klaas Bentein

Mark Janse

Jorie Soltic

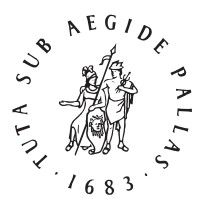

B R I L L

LEIDEN | BOSTON

For use by the Author only | (c) 2017 Koninklijke Brill NV 


\section{Contents}

Preface VII

List of Figures VIII

List of Tables IX

List of Abbreviations $\quad \mathrm{X}$

List of Contributors XI

1 Introduction 1

Klaas Bentein, Mark Janse and Jorie Soltic

2 Subjunctive and Optative in Herodotus' Purpose Clauses as Relative Tense Markers 9

Antonio Lillo

3 Variation in Expressing Temporal and Aspectual Distinctions in Complement Clauses: A Study of the Greek Non-Literary Papyri of the Roman Period 22

Jerneja Kavčič

4 Syntactic Variation with Verbs of Perception and the 'Oblique Imperfect': Once Again on Aspect, Relative Time Reference and Purported Tense-Backshifting in Ancient Greek $\quad 5^{6}$ Julián Méndez Dosuna

5 The Gnomic Aorist in Hesiod 84 Gerry C. Wakker

6 The Imperfect Unbound. A Cognitive Linguistic Approach to Greek Aspect 100

Rutger J. Allan

$7 \quad$ Aktionsart, Aspect and Category Change in the History of Greek 131 Amalia Moser

$8 \quad \Omega \varphi \varepsilon \lambda(\lambda) \circ v$ in Ancient Greek Counterfactual Desiderative Sentences: From Verb to Modal Particle 158

Antonio R. Revuelta Puigdollers

For use by the Author only | (c) 2017 Koninklijke Brill NV 
$9 \quad$ Modalized Future and Scheduled Present in Coan Inscriptions 189 Marina Veksina

$10 \quad$ 'High' and 'Low' in Medieval Greek 219

Geoffrey Horrocks

11 Confusion of Moods in Greek Private Letters of Roman Egypt? 242 Martti Leiwo

12 Register Variation and Tense/Aspect/Mood Categories in Ancient Greek: Problems and Perspectives $\quad 261$

Andreas Willi

Index locorum $\quad 287$

Index nominum et rerum 297 


\section{Introduction}

Klaas Bentein, Mark Janse and Jorie Soltic

If structure is at the heart of language, then variation defines its soul. WOLFRAM 2006:333

\subsection{Setting the Scene}

Variation was long considered a problem in linguistic theory, one from which attention needed to be deflected. ${ }^{1}$ Yet nowadays variation has become a central concept in variationist (socio)linguistics, ${ }^{2}$ a discipline which draws attention to its synchronic and diachronic importance, for variation is ubiquitous in language, and can be considered 'the inevitable synchronic face of long-term change' (Guy 2003:370).

This variationist approach has mainly been adopted in relation to the spoken language, which can be most accurately observed, described and analysed. Written texts have received relatively little attention, with Labov (1994:11) describing historical linguistics as 'the art of making the best use of bad data'. Scholars have come to realize, however, that written texts also form a valuable object of investigation and that research into spoken language faces its own methodological difficulties. As a result, 'socio-historical' linguistics has, in recent years, become established as a discipline. ${ }^{3}$

The main purpose of this volume is to explore linguistic variation in Ancient Greek texts, concentrating on one of the core areas of grammar: tense, aspect

1 See e.g., Dufter-Stark (2008:81): 'La variation à l' intérieur d' une langue historique fut considérée comme noise dont il fallait absolument minimiser l'influence'.

2 The term 'variationist linguistics' is broader than 'sociolinguistics', with the latter focusing specifically on socially related variation. The two terms are often combined as 'variationist sociolinguistics'.

3 Romaine (1982) is a pioneering work. 
and modality (commonly abbreviated as TAM). ${ }^{4}$ The different chapters explore a number of central research questions, such as:

- Which domains of variation (e.g., syntax, semantics, morphology) can be related to the categories of tense-aspect-modality?

- Which dimensions of variation (e.g., diachrony, register/style, dialect) are relevant?

- Which forces stimulate linguistic variation? What role does the existing linguistic system play?

- What does variation look like from a synchronic point of view?

- How is the synchronic competition between variant expressions resolved from a diachronic point of view?

- What can modern linguistic theory contribute to the study of variation?

- How might variation be approached? What is the value of quantitative vs. qualitative approaches?

The present volume does not limit itself to one specific research question: the contributors were asked to focus on tense, aspect and modality, but were stimulated to discuss these phenomena from various time periods, and to take different approaches. We thus hope that this volume will stimulate the further investigation of (TAM-related) linguistic variation in Ancient Greek. ${ }^{5}$

\subsection{Some Theoretical Background}

The space available for this introduction is too limited for us to provide a full background to the variationist literature and its application to Ancient Greek. It is worth giving some historical background, however, as well as introducing some central concepts. Variationist (socio)linguistics can be traced back to the 1960s, and in particular to the work of William Labov. Hymes (1974) observes that the study of linguistic variation followed that of phonology, morphology, syntax and semantics:

4 A terminological note is in order here. The TAM-triad is often referred to as tense, aspect and mood. Since we understand these categories in a functional (rather than a formal) sense, we prefer 'modality' over 'mood'.

5 For another recent volume on linguistic variation, see Leiwo et al. (2012). This volume takes an even broader approach as it does not focus on one specific linguistic area, and deals with both Latin and Greek. 
To a great extent it was the conquest of speech sounds as an area of pattern belonging to linguistics that gave structural linguistics its impetus [...]. Morphology came to be intensively cultivated in the late 1930s and the 1940s. Syntax came more to attention in the 1950s [...]. Semantics has become a major concern in the 1960 s [...]. Very recently the notion of sociolinguistic description has been advanced.

HYMES 1974:89-90

In the variationist literature, it is common to distinguish between a number of dimensions of variation (see e.g., Seidl \& Wirth 2008). According to the model first introduced by Coseriu (1969), four such dimensions can be distinguished: (a) the 'diachronic' dimension (variation in time); (b) the 'diatopic' dimension (variation in space); (c) the 'diastratic' dimension (variation according to the speaker's social status); and (d) the 'diaphasic' dimension (variation in communicative settings). ${ }^{6}$ The diastratic/diaphasic dimension lies at the heart of modern-day sociolinguistics: various models have been introduced to connect language to its social context, centering around notions such as 'politeness', 'register', and 'accommodation'.7 Some of these have been applied to Ancient Greek (for further details see Bentein 2016).

Next to dimensions of variation, we can also recognize domains of variation (see e.g., Croft 2006:98-103). Three main types of variation are distinguished in this regard, corresponding to the three main areas in grammar: (a) phonetic variation (e.g., pronunciation vs. non-pronunciation of final $\mathrm{t} / \mathrm{d}$ in words such as 'soft' and 'missed'); (b) lexical variation (e.g., 'trousers' vs. 'pants'); and (c) morpho-syntactic variation (e.g., 'there is a lot of people' vs. 'there are a lot of people'). A key construct in the study of these different types of variation is that of the 'variant field' (see e.g., Rydén 1987), denoting a pool of linguistic features that are considered roughly equivalent. ${ }^{8}$

6 There is some discussion with regard to these dimensions. Considerable overlap exists between the diaphasic and diastratic dimensions in particular, to the extent that one could doubt whether any real distinction can be made. (Coseriu, for example, originally considered factors such as age, occupation and sex to belong to the diaphasic dimension, see Dufter-Stark 2008:87.) Other scholars argue that yet another dimension should be introduced, that is, communicative immediacy vs. communicative distance (Dufter-Stark 2008:90-94).

7 See Eckert (2012) for a historic overview. Eckert (2012:87) argues that 'the treatment of social meaning in sociolinguistic variation has come in three waves of analytic practice'.

8 This 'equivalency', especially concerning lexical and syntactic variation, has been subject to considerable debate. 
Slightly less common is the distinction made by Croft (2006:98-103) between levels of variation: ${ }^{9}$ (a) first-order variation (individual utterances, e.g., a student who always writes 'chose' for 'choose'); (b) second-order variation (sociallyvalued variants, e.g., copula deletion in Black English Vernacular, as in 'you from outta town'); and (c) third-order variation (linguistic differences across dialects and languages, e.g., the pronunciation of 'tomato' in American vs. British English [tə'mertoð/tə'ma:təð]). Generally speaking, interest in language variation focuses on second- and third-order variation. As Wolfram (2006:333) notes, however, 'socially meaningful aspects of individual speaker performance are of interest to those interested in language variation. ${ }^{10}$

Within variationist linguistics, two main approaches can be identified: the 'qualitative' and the 'quantitative' approaches. In the former type, exhaustive and detailed analysis is central, attention being paid to both rare and more frequent phenomena; in quantitative analysis, features are classified and counted on the basis of which generalizations are made (McEnery \& Wilson 2001:76). In variationist linguistics, quantitative analysis has dominated. As Leiwo (2012:2) notes, however, this quantitative methodology has not been easy for languages such as Ancient Greek, 'because of the lack of adequate linguistically-annotated corpora:.11 Moreover, when dealing with restricted data (e.g., 'first-order' variation), qualitative analysis forms the starting point. Often the two approaches complement each other.

When it comes to Ancient Greek, many papers and books deal with linguistic variation. When we apply the above-discussed notions, however, it turns out that they have a rather specific profile: they typically discuss diachronic, and especially diatopic variation in the Classical period, ${ }^{12}$ focusing on phonology and morphology. ${ }^{13}$ Much rarer are works dealing with diastratic/diaphasic

$9 \quad$ For an application to Ancient Greek, see Bentein (2012).

10 Evans (2010), for example, draws attention to the interest of individual linguistic preferences in documentary papyri.

11 Several such projects are underway, however. Most of these focus on the Post-classical period: see e.g., Dag Haug's Proiel-project, Marja Vierros' sematia, and PorterO'Donnell's OpenText.org. At Ghent University, Klaas Bentein is compiling a corpus of linguistically and socio-pragmatically annotated Roman and Byzantine papyri. Mention should also be made of the Perseus database.

12 For the latest outline of (the history of) Greek dialectology, see e.g., Consani (2014).

13 In the recently published Encyclopedia of Ancient Greek language and linguistics (Giannakis 2014), for example, there is a separate article for 'Linguistic variation in Classical Attic' (Poccetti 2014), but none for the other historical periods (see more generally, Consani 2014). 
variation in the Post-classical and Byzantine periods, focusing on lexical and syntactic variation. Moreover, a common characteristic of several studies and grammars is that they are 'taxonomic' in nature: they list variation, but do not explain the reasons or chronology behind it (Leiwo 2012:5). The present volume attempts to offer a more balanced picture by discussing variation in a functional area over a broad period of time.

\subsection{Outline of the Volume}

That the notions of tense, aspect, and modality are interconnected is a wellknown fact (see, for example, the discussion about whether the future should be considered in terms of tense or modality, and similarly, whether the perfect should be considered in terms of tense or aspect; as well as the observation that perfective aspect typically combines with past tense in the indicative). The volume is organized as follows: the first three papers are concerned with tense (ch. 2-4), the next three papers with aspect (ch. 5-7), and the following four papers with modality (ch. 8-11). The volume ends with a paper that contains some more general, methodological considerations, with illustrations from all three functional areas (ch. 12).

In the area of tense, the main topic concerns the expression of relative tense (or the absence thereof), through various modes of realization. Antonio Lillo (ch. 2) discusses the use of subjunctive and optative in purpose clauses introduced by iv $\nu$ and $0 ँ \omega \omega$, focusing on Herodotus' Histories. He argues that the choice for one or the other is a matter of relative tense, rather than primary versus secondary purpose (as is traditionally assumed for Homer): "The optative in purpose sentences reports an action in the present with respect to the action of the main clause, while the subjunctive reports an action in the future with respect to the action of the main clause'. In both cases, the main clause can contain a primary or secondary tense. Jerneja Kavčič (ch. 3) analyzes the use of the infinitive in complement clauses following verbs of saying/thinking, focusing on a corpus of documentary papyri from the Roman period. She observes that the aorist infinitive tends to be excluded from this type of complementation pattern, and that there is a tendency towards the use of the present infinitive for simultaneity, the perfect infinitive for anteriority and the future infinitive for posteriority. Interestingly, the aorist does appear more often in complement clauses introduced by ö $\tau \iota$ or $\dot{\omega} \varsigma$. The spirit of the final tense-related paper (ch. 4) is somewhat different from that of these first two papers: Julián Méndez Dosuna opposes the view that relative tense was an operative category in the grammar of Ancient (Classical) Greek. He draws attention to the 
fact that verbs of immediate perception, which necessarily take a temporally simultaneous complement, can be followed by a present or aorist participle.

The following three papers concern aspect and are more varied in nature. Gerry Wakker (ch. 5) discusses expressions of omnitemporality, concentrating on the use of the so-called 'gnomic' aorist. After studying the possible origin of the gnomic aorist, she discusses its synchronic value in Hesiod's Theogony and Works and Days. Another question she addresses is how the gnomic aorist relates to the omnitemporal present tense. Rutger Allan (ch. 6) treats aspectual variation with verbs of motion and speech in Thucydides. In a number of cases where the aorist might be expected, the imperfect tense is used for completed states of affairs. Allan focuses on one specific use, called the 'imperfect of continuing relevance', which he distinguishes from 'the imperfect creating a temporal framework', and 'the discourse-structuring imperfect'. In the second part of his paper, Allan argues for the benefits of modern linguistic theory, Cognitive Linguistics in particular, for our understanding of this particular use of the imperfect. Amalia Moser (ch. 7) offers the most general discussion: she discusses the relationship between the categories of aspect and Aktionsart, covering a very broad time period (from Archaic to Standard Modern Greek). Moser argues that while there has been little change morphologically, the system itself has been altered in a fundamental way: the three stems have shifted from the expression of Aktionsart to the expression of aspect. To demonstrate this, she examines a corpus of historiographical texts.

The authors treat various topics in the functional area of modality also, using different methodologies and corpora. Antonio Revuelta Puigdollers (ch. 8) discusses the grammaticalization of (counterfactual) desiderative constructions introduced by $\omega^{\prime} \varphi \varepsilon \lambda(\lambda) \circ v$, from Homer up to the 2nd c. CE. He describes in detail how $\omega \varphi \varepsilon \lambda(\lambda)$ ov developed from an auxiliary verb into an illocutionary particle (semantically and morpho-syntactically), and also outlines several other constructions competing for the expression of desire (such as ${ }^{\prime} \theta \varepsilon / \alpha i \theta \varepsilon, \varepsilon i / \alpha i \gamma \alpha \dot{\alpha} \rho, \dot{\omega} \varsigma$ with the optative and $\dot{\varepsilon} \beta 0 u \lambda o^{\prime} \mu \eta \nu$ with the infinitive). Marina Veksina (ch.9) analyzes mood fluctuations in Coan inscriptions, showing that whereas in decrees on sacral matters the substance is normally expressed in the imperative, the present indicative and future indicative can also express permission/obligation. Similarly to Antonio Revuelta Puigdollers' contribution, Marina Veksina's analysis is well embedded in current linguistic theory. Geoffrey Horrocks (ch. 10) concentrates on futurity-related expressions in a period and corpus that has received relatively little attention so far, that is, later Medieval Greek. He argues for the need to investigate both lower and higher registers. The language of high-register texts is often considered identical to that of the Classical period, but this, Horrocks shows, is not the case. By way of illustration, 
he analyses the use of the indicative future, subjunctive and optative in Anna Comnene's Alexiad. Finally, Martti Leiwo's paper (ch. 11) concentrates on confusion of moods in documentary texts from Mons Claudianus. He notes that in many documents there is variation between the infinitive, participle and imperative, arguing that this variation may be both language-internal and contact-induced, drawing attention to the possible influence of Coptic. Leiwo's discussion concentrates on the idiolectal level: he argues that a small set of data can show ongoing trends in language use, trends which are relevant at a higher level as well.

In the article that concludes the volume, Andreas Willi (ch. 12) offers some more general considerations centered around the notion of 'register'. He investigates the extent to which it is possible to determine an interrelation between linguistic registers and certain distributional patterns in the use of various grammatical phenomena relating to tense/aspect/mood, and stresses the importance of paying attention to both synchronic and diachronic aspects of register variation, and of being aware of the dialectal diversity of Ancient Greek when investigating registers. Another important point that is made concerns the need to account for certain register-specific grammatical preferences. By way of illustration, Willi draws attention to the frequency of the so-called 'resultative' perfect in oratory.

\section{References}

Bentein, K. 2012. 'Perfect periphrases in Post-classical and Early Byzantine Greek: an ecological-evolutionary account'. JGL 12:205-275.

Bentein, K. 2016. 'Towards a socio-historical analysis of Ancient Greek? Some problems and prospects'. Towards a sociolinguistic approach to textual interpretation, ed. by E. Trapp \& A. Cuomo. Turnhout. In print.

Consani, C. 2014. 'Ancient Greek sociolinguistics and dialectology'. In: Giannakis 2014:117-124.

Coseriu, E. 1969. Einführung in die strukturelle Linguistik. Tübingen.

Croft, W. 2006. 'The relevance of an evolutionary model to historical linguistics'. Different models of linguistic change, ed. by O. Nedergård Thomsen, 91-132. Amsterdam.

Dufter, A. \& E. Stark. 2002. 'La variété des variétés: combien de dimensions pour la description?' RJb 53:81-108.

Eckert, P. 2012. 'Three waves of variation study. The emergence of meaning in the study of sociolinguistic variation'. ARA 41:87-100.

Evans, T.V. 2010. 'Identifying the language of the individual in the Zenon Archive'. The language of the papyri, ed. by T.V. Evans \& D. Obbink, 51-70. Oxford. 
Giannakis, G. (ed.). 2014. Encyclopedia of Ancient Greek language and linguistics. Leiden. Guy, G. 2003. 'Variationist approaches to phonological change'. The handbook of historical linguistics, ed. by B. Joseph \& R. Janda, 369-400. Oxford.

Hymes, D. 1974. Foundations in sociolinguistics: an ethnographic approach. Philadelphia. Labov, W. 1994. Principles of linguistic change. I: Internal factors. Oxford.

Leiwo, M., Halla-aho, H. \& M. Vierros (eds.). 2012. Variation and change in Greek and Latin. Helsinki.

Leiwo, M. 2012. 'Introduction: variation with multiple faces'. In: Leiwo et al. 2012:1-12. McEnery, T. \& A. Wilson. 2001. Corpus linguistics: an introduction. Edinburgh.

Poccetti, P. 2014. 'Linguistic variation in Classical Attic'. In: Giannakis 2014:364-367.

Romaine, S. 1982. Socio-historical linguistics: its status and methodology. Cambridge.

Rydén, M. 1987. 'Syntactic variation and paradigmatic typology'. $s L$ 41:48-58.

Seidl, C. \& T. Wirth. 2008. 'Eine Sprache ist kein Monolith'. BSAV 72:5-18.

Wolfram, W. 2006 ${ }^{2}$. 'Variation and language: an overview'. Encyclopedia of language and linguistics, ed. by K. Brown, 333-341. Oxford. 